\title{
Pengaruh Penerapan Model Pembelajaran Learning Cycle 7E terhadap Keterampilan Proses Sains Siswa pada Materi Koloid di SMA Negeri 10 Pekanbaru
}

\author{
Meri Andani ${ }^{1}$, Lisa Utami ${ }^{2}$ \\ ${ }^{1}$ Program studi Pendidikan Kimia, Universitas Islam Negeri Sultan Syarif Kasim Riau \\ ${ }^{2}$ Program studi Pendidikan Kimia, Universitas Islam Negeri Sultan Syarif Kasim Riau \\ e-mail: \\ 1'meriandani1609@gmail.com \\ 21154_lazoelva@yahoo.com
}

\begin{abstract}
.
This study aims to determine the effect of the application of the 7E Learning Cycle learning model on science process skills of students in colloidal material in class XI Senior High School 10 Pekanbaru. The population of this study was all students of class XI consisting of 6 classes and the study sample was students of class XI IPA 3 as an experimental class and class XI IPA 2 as a control class. This study used a quasi-experimental method with a pretest posttest non-equivalent control group design. Data collection instruments in this study used tests, observations, and documentation. To find out the influence of the learning model on science process skills students after the treatment was held, it can be seen from the data on the difference between the pretest and posttest values between the experimental class and the control class. Data processing techniques are carried out quantitatively, namely by using a $t$-test. Based on the results of the analysis with the t-test test, the value of $t_{\text {count }}=2.80$ and $t_{\text {table }}=2.00$ and shows $t_{\text {count }}>t_{\text {table }}$ so that $\mathrm{Ho}_{\mathrm{i}}$ is rejected and $\mathrm{Ha}$ is accepted. Based on the results of the analysis, it can be concluded that there is an influence of the application of the $7 E$ Learning Cycle learning model to science process skills of students with an influence coefficient of $10.8 \%$.
\end{abstract}

Keywords: science process skills, learning cycle 7e learning model, colloids

\begin{abstract}
ABSTRAK.
Penelitian ini bertujuan untuk mengetahui pengaruh penerapan model pembelajaran Learning Cycle 7E terhadap keterampilan proses sains siswa pada materi koloid di kelas XI IPA SMA Negeri 10 Pekanbaru. Populasi penelitian ini adalah seluruh siswa kelas XI yang terdiri dari 6 kelas dan sampel penelitian adalah siswa kelas XI IPA 3sebagai kelas eksperimendan kelas XI IPA 2sebagai kelas kontrol. Penelitian ini menggunakan metode kuasi eksperimen dengan rancangan pretest posttest non-equivalent control group design. Instrumen pengumpulandata dalam penelitian ini menggunakan tes, observasi, dan dokumentasi. Untuk mengetahuipengaruh model pembelajaran terhadap keterampilan proses sains siswa setelah diadakan perlakuan, dapat dilihat dari data selisih nilai pretest dan posttest antara kelas eksperimen dan kelas kontrol. Teknik pengolahan data dilakukan secara kuantitatif, yaitu dengan menggunakan t-test. Berdasarkan hasil analisis dengan uji t-test diperoleh nilai thitung $=2,80$ dan $t_{\text {tabel }}=2,00$ dan menunjukkan thitung $>t_{\text {tabel }}$ sehingga Ho ditolak dan Ha diterima. Berdasarkan hasil anallisis tersebut dapat disimpulkan bahwaada pengaruh penerapan model pembelajaran Learning Cycle $7 E$ terhadap keterampilan proses sains siswa dengan koefisien pengaruh sebesar $10,8 \%$.
\end{abstract}

Kata kunci: keterampilan proses sains,model pembelajaran learning cycle 7e, koloid 


\section{PENDAHULUAN}

Keterampilan proses ilmiah penting dimiliki setiap individu sebab keterampilan tersebut digunakan dalam kehidupan sehari-hari dan meningkatkan kemampuan ilmiah (Hilman, 2014). Pendekatan keterampilan proses adalah suatu pendekatan pengajaran yang memberi kesempatan kepada siswa untuk ikut menghayati proses penemuan atau penyusunan suatu konsep sebagai suatu keterampilan proses sains (Avianti, R., \& Bertha Yonata, 2015). Keterampilan proses sains juga merupakan keterampilan yang melibatkan segenap kemampuan siswa dalam memperoleh pengetahuan berdasarkan fenomena. Kemampuan siswa yang dimaksud adalah keterampilan mengamati, mengelompokkan, menafsirkan, memprediksi, mengajukan pertanyaan, berhipotesis, merencanakan percobaan, menggunakan alat dan bahan, menerapkan konsep, berkomunikasi dan melaksanakan percobaan.

Keterampilan proses sains penting dalam pembelajaran saat ini karena perkembangan ilmu pengetahuan dan teknologi berlangsung semakin cepat sehingga tidak mungkin lagi guru mengajarkan semua konsep dan fakta kepada siswa, adanya kecenderungan bahwa siswa lebih memahami konsep-konsep yang rumit dan abstrak jika disertai dengan contoh yang konkret dan dalam proses belajar mengajar pengembangan konsep tidak terlepas dari pengembangan sikap dan nilai dalam diri anak didik (Wahyudi, A., Marjono \& Harlita, 2015).

Pentingnya keterampilan proses sains dapat dicermati dalam kurikulum pendidikan khususnya pada mata pelajaran IPA. Sebagian besar kompetensi dasar yang tertuang dalam standar ini secara eksplisit menegaskan pembelajaran IPA selalu menyandingkan keterampilan proses sebagai pengalaman belajar dan pemahaman konsep sebagai tujuan pembelajaran. Sehingga kurang proporsionalitas apabila siswa diharapkan mencapai tujuan tetapi dengan pengalaman belajar yang pasif (Hilman, 2014). Tujuan tersebut mampu memberikan kepuasan intelektual terutama dalam membangun keterampilan berpikir yang mengimplikasikan terhadap pengetahuan (kognitif), sikap (afektif), dan keterampilan (psikomotorik). Ayat Al-Qur'an yang mendukung bahwa manusia hendaknya membangun keterampilan berpikirnya sendiri yaitu pada Surat An-Nahl ayat 78 yang berbunyi:

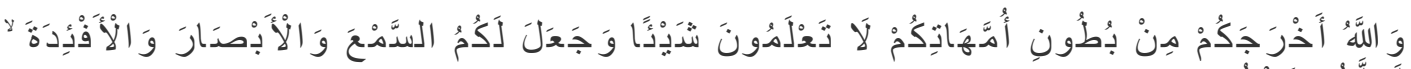

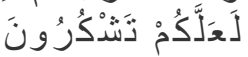

Artinya: "Dan Allah mengeluarkan kamu dari perut ibumu dalam keadaan tidakmengetahui sesuatu pun, dan dia memberimu pendengaran, penglibatan danhati nurani, agar kamu bersyukur".

Berdasarkan Al-Qur'an Surat An-Nahl ayat 78 mengisyaratkan ciri khas manusia yang paling penting dan paling bernilai, yakni kemampuan berpikir dan mencerna sesuatu, dan apa yang kita ketahui saat ini diserap dengan bantuan mata, telinga, dan akal yang diberikan Allah kepada kita. Maka hendaknya kita bersyukur kepada Allah yang sudah memberikan nikmat-Nya, sehingga kita bisa menjadi manusia yang dapat menjalani kehidupan dengan baik.

Kimia merupakan salah satu mata pelajaran pada rumpun sains yang erat kaitannya dengan kehidupan sehari-hari. Dalam pembelajaran kimia harus memperhatikan karakteristik hakikat sains yaitu sains sebagai sikap, proses, produk, dan aplikasi (Avianti, R., \& Bertha Yonata, 2015). Salah satu materi kimia yang melibatkan keterampilan proses sains dalam meningkatkan pemahaman konsep sains adalah materi koloid (N Purba, M., Ila Rosilawati \& Tasviri Efkar, 2016).

Akan tetapi, kenyataannya keterampilan proses sains siswa disekolah masih rendah, hal ini dibuktikan dengan hasil angket yang penulis lakukan kepada 30 siswa kelas XI (IPA 1, IPA 2, IPA 3) pada SMA Negeri 10 Pekanbaru, diperoleh hasil bahwa dari 10 indikator keterampilan proses yang disajikan dalam angket siswa, hasilnya didapatkan 3 indikator (menafsirkan, memprediksi, dan merencanakan percobaan) dalam kategori rendah, dan 2 indikator (klasifikasi dan menerapkan 
konsep) dalam kategori sedang. Dengan demikian, hanya $42 \%$ dari 30 orang responden yang memenuhi keterampilan proses sains dengan kategori tinggi dan sangat tinggi.

Selain itu, salah satu faktor yang mempengaruhi keterampilan proses sains siswa adalah model pembelajaran yang digunakan oleh guru. Keterampilan proses sains dapat meningkat apabila model pembelajaran yang diterapkan sesuai dengan karakteristik materi (Rohaniyah, W., dan Utiya Azizah, 2017). Keterampilan proses sains dapat terlatihkan karena terjadi aktivitas ilmiah pada pembelajaran (Wahyudi, A., Marjono \& Harlita,2015). Namun siswa masih kurang melakukan aktivitas ilmiah disekolah, hal ini berdasarkan hasil wawancara dengan guru mata pelajaran kimia, dimana disekolah guru masih menggunakan metode ceramah, diskusi informasi dan praktikum. Metode praktikum sudah dilakukan guru pada beberapa materi seperti materi asam basa, larutan penyangga dan hidrolisis. Akan tetapi, pada saat praktikum siswa hanya dilatih keterampilan dalam menggunakan alat, sedangkan keterampilan proses sains yang lain belum dilakukan sehingga perlu dilakukan suatu metode praktikum agar siswa dapat lebih dilatihkan pada keterampilan proses sains.

Untuk mengatasi permasalahan tersebut maka paradigma pembelajaran harus diubah menjadi pembelajaran yang berpusat pada siswa (student centered) dimana siswa mencoba menemukan dan membangun sendiri konsep materi yang diajarkan dengan bimbingan guru sebagai fasilitator sehingga orientasi pembelajaran cenderung mengacu pada teori kontuktivis (Dian Permana, N., Ida Hamidah \& Agus Setiawan, 2015). Pembelajaran dengan metode yang terpusat pada guru atau teacher centre akan menjadikan proses pembelajaran yang kaku, kurang mengembangkan pengetahuan, sikap dan keterampilan siswa. Oleh karena itu, untuk meningkatkan keterampilan proses sains siswa dibutuhkan model pembelajaran yang membuat siswa aktif selama proses pembelajaran. Siswa seharusnya memperoleh pengetahuan dari proses pembelajaran yang diikutinya (Tania, B., dan Murni, 2017).

Pendekatan konstruktivis sangat cocok digunakan untuk mata pelajaran IPA yang merupakan salah satu bidang ilmu yang tidak hanya berupa kumpulan fakta tetapi juga memerlukan serangkaian proses ilmiah untuk memperoleh fakta tersebut. Selain itu teori kontruktivisme juga dapat menumbuhkan kemampuan berpikir tingkat tinggi siswa seperti keterampilan berpikir kritis, kreatif dan keterampilan proses sains siswa (Dian Permana, N., 2018). Salah satu model pembelajaran yang konstruktivis adalah model pembelajaran Learning Cycle 7E (Kartikawati, A., dan Utiya Azizah, 2017).

Learning Cycle 7E adalah model pembelajaran dengan pendekatan konstruktivisme dan berpusat pada siswa (Rohaniyah, W., dan Utiya Azizah, 2017). Model pembelajaran Learning Cycle $7 \mathrm{E}$ juga merupakan suatu model pembelajaran yang berbasis konstruktivis yang mengakibatkan siswa dapat mengembangkan pemahaman terhadap pengetahuan yanng diterima melalui kegiatan mencoba dan diskusi atau memperoleh informasi dari buku sehingga pengetahuan yang diperoleh akan lebih bermakna selain itu melalui tahapan-tahapan model pembelajaran Learning Cycle 7E ini siswa dapat melatihkan keterampilan proses sains (Kartikawati, A., dan Utiya Azizah, 2017).

Learning Cycle cocok diterapkan pada pembelajaran yang bersifat hafalan, perhitungan, eksperimen, pemahaman materi, dan penerapan dalam kehidupan sehari-hari. Oleh karena itu diharapkan model pembelajaran Learning Cycle 7E dapat diterapkan untuk pembelajaran materi koloid karena sesuai dengan karakteristik materi sistem koloid yang terdiri atas kegiatan praktikum dan diharapkan dapat meningkatkan keterampilan proses sains siswa (Diana Rosa, Dinda., dan Utiya Azizah, 2017).

Hasil penelitian yang menerapkan model pembelajaran Learning Cycle 7E diantaranya terbukti dapat meningkatkan keterampilan berpikir kritis siswa dengan model pembelajaran Learning Cycle 7E berbantuan website pada materi kinetika gerak lurus (Dian Permana, N., 2018). Begitu juga dengan penelitian yang dilakukan Wahyuni Rohaniyah dan Utiya Azizah, 2017) bahwa 
keterlaksanaan model Learning Cycle 7E untuk meningkatkan keterampilan proses sains siswa pada materi laju reaksi dengan mendapat kategori sangat baik dan baik.

Berdasarkan pada uraian latar belakang tersebut, penulis tertarik untuk melakukan penelitian dengan judul pengaruh penerapan model pembelajaran Learning Cycle 7E terhadap keterampilan proses sains siswa pada koloid. Aspek keterampilan proses sains yang diteliti dalam penelitian ini meliputi 1) Aspek observasi/ mengamati (indikator: menggunakan sebanyak mungkin indra), 2) Aspek klasifikasi/ mengelompokkan (indikator: mencatat setiap pengamatan), 3) Aspek interpretasi/ menafsirkan (indikator: menyimpulkan), 4) Aspek melakukan komunikasi (indikator: menjelaskan hasil percobaan), 5) Aspek mengajukan pertanyaan (indikator: bertanya apa, bagaimana, mengapa), 6) Aspek mengajukan hipotesis (indikator: menyadari bahwa suatu penjelasan perlu diuji kebenarannya dengan memperoleh bukti), 7) Menggunakan alat/bahan (indikator: memakai alat/ bahan, mengetahui bagaimana menggunakan alat/bahan), 8) Menerapkan konsep (indikator: menerapkan konsep pada situasi baru)

\section{Model Pembelajaran Learning Cycle $7 E$}

Model pengajaran sains yang berbasis kontruktivisme dan metode pengajarannya berpusat pada siswa adalah Learning Cycle (siklus belajar), dikembangkan lebih dari 30 tahun yang lalu. Model pengajaran siklus belajar ini awalnya diajukan oleh Robet Karplus. Model ini berdasarkan pada teori Piaget dan melibatkan pengajaran dengan pendekatan kontruktivisme. Model siklus belajar bertujuan membantumengembangkan berpikir siswa dari berpikir konkrit ke abstrak (atau dari konkrit ke formal).

Pada awalnya model pembelajaran Learning Cycle hanya memilki 3 fase yaitu exploration, introduction, dan application. Sesuai perkembangan, versi siklus belajar bermunculan dalam kurikulum sains dengan fase yang berkisar dari tiga kelima (5E) sampai tujuh (7E). Siklus 5E berdasarkan pengajaran yang dibangun oleh biological Sciences Curriculum Study (BSCS) pada tahun 1989, terdiri dari lima fase yaitu engage, explore, explain, elaborate dan evaluate. Setelah siklus belajar mengalami pengkhususan menjadi 5 tahapan, maka pengembangan siklus belajar menjadi 7 tahapan. Perubahan yang terjadi pada tahapan siklus 5E menjadi 7E terjadi pada tahap engage menjadi 2 tahapan yaitu menjadi elecit dan engage, sedangkan pada tahap elaborate dan evaluate menjadi 3 tahapan yaitu menjadi tahap elaborate dan evaluate dan extend(Yunita, 2012).. Einsekraft mengembangkan siklus belajar mulai dari Learning gycle $3 E$ ke 5-E sampai 7-E meliputi elicit (pemerolehan), engage (perlibatan), explore (eksplorasi), explain (penjelasan), elaborate (elaborasi), evaluate (evaluasi), dan extend (perluasan) (Diana Rosa, Dinda., dan Utiya Azizah, (2017).

Model pembelajaran Learning cycle 7E memiliki 7 tahap/fase antara lain, elicit (tahapan mendatangkan atau memunculkan pengetahuan awal siswa); engage (tahapan merangsang ide dan memotivasi siswa); explore (tahapan siswa mendapatkan pengetahuan melalui pengalaman langsung); explain (tahapan siswa untuk memaparkan konsep); elaborate (tahapan siswa menerapkan simbol, definisi, atau konsep), evaluate (tahapan evaluasi dari pembelajaran yang telah dilakukan); extend (tahapan siswa dalam menghubungkan konsep yang dipelajari dengan konsep lain) (Rohaniyah, W., dan Utiya Azizah, 2017).

Model pembelajaran Learning Cycle $7 E$ adalah salah satu model pembelajaran yang berbasis penemuan, karena dalam sintaks pembelajaran Learning Cycle $7 E$ mengarahkan siswa menemukan konsep, hukum dan teori serta menerapkan dan menjelaskan contoh penerapan konsep yang telah dipelajari. Model pembelajaran Learning Cycle $7 E$ merupakan salah satu model pembelajaran yang memiliki keunggulan dalam pelaksanaan pendidikan karena akan menghasilkan pemahaman konsep-konsep ilmiah, pemikiran dan sikap siswa terhadap pembelajaran sains (Diana Rosa, Dinda., dan Utiya Azizah, (2017). Eisenkraft mengungkapkan ketujuh tahapan itu meliputi: 
Elecit (mendatangkan pengetahuan awal siswa), yaitu fase untuk mengetahui sampai dimana pengetahuan awal siswa terhadap pelajaran yang akan dipelajari dengan memberikan pertanyaanpertanyaan yang merangsang pengetahuan awal agar timbul respon dari pemikiran siswa serta menimbulkan kepenasaranan tentang jawaban dari pertanyaan-pertanyaan yang diajukan oleh guru.

Engage (ide, rencana pembelajaran dan pengalaman), yaitu fase dimana siswa dan guru dan saling memberikan informasi dan pengalaman tentang pertanyaan-pertanyaan awal tadi, memberitahukan siswa tentang ide dan rencana pembelajaran sekaligus memotivasi siswa agar lebih berminat untuk mempelajari konsep dan perhatian guru dalam mengajar.

Explore (menyelidiki), yaitu fase yang membawa siswa untuk memperoleh pengetahuan dengan pengalaman langsung yang berhubungan dengan konsep yang akan dipelajari. Siswa dapat mengobservasi, bertanya, dan menyelidiki konsep dari bahan-bahan pembelajaran yang telah disediakan sebelumnya.

Explain (menjelaskan), yaitu fase yang didalamnya berisi ajakan terhadap siswa untuk menjelaskan konsep-konsep dan definisi-definisi awal yang didapatkan ketika fase eksplorasi. Kemudian dari definisi dan konsep yang telah ada didiskusikan sehingga pada akhirnnya menuju konsep dan definisi yang lebih formal.

Elaborate (menerapkan), yaitu fase yang bertujuan untuk membawa siswa menerapkan simbol - simbol, defenisi - definisi, konsep - konsep, dan keterampilan - keterampilan pada permasalahan - permasalahan yang berkaitan dengan contoh dari pelajaran yang dipelajari.

Evaluate (menilai), yaitu fase evaluasi dari hasil pembelajaran yang telah dilakukan. Pada fase ini dapat digunakan berbagai strategi penilaian formal dan informal.

Extend (memperluas), yaitu fase yang bertujuan untuk berpikir, mencari, menemukan dan menjelaskan contoh penerapan konsep yang telah dipelajari bahkan kegiatan ini dapat merangsang siswa untuk mencari hubungan konsep yang dipelajari dengan konsep lain yang sudah atau belum dipelajari (Yunita, 2012).

\section{Keterampilan Proses Sains}

Keterampilan proses merupakan keseluruhan keterampilan ilmiah yang terarah (baik kognitif maupun psikomotor) yang dapat digunakan untuk menemukan suatu konsep atau prinsip atau teori, untuk mengembangkan konsep yang telah ada sebelumnya ataupun untuk melakukan penyangkalan terhadap suatu penemuan. Dengan kata lain keterampilan ini dapat digunakan sebagai wahana penemuan dan pengembangan konsep/prinsip/teori. Konsep/prinsip/teori yang telah ditemukan atau dikembangkan ini akan memantapkan pemahaman tentang keterampilan proses tersebut (Trianto, 2011).

Menurut Semiawan, pendekatan keterampilan proses dapat diartikan sebagai wawasan atau panutan pengembangan keterampilan-keterampilan intelektual, sosial, dan fisik yang bersumber dari kemampuan-kemampuan mendasar yang pada prinsipnya telah ada dalam diri siswa (Tahwil, M., dan Liliasari, 2014). Senada dengan hal tersebut, Kumiati mengungkapkan bahwa pendekatan keterampilan proses adalah pendekatan yang memberi kesempatan kepada siswa agar dapat menemukan fakta, membangun konsep-konsep, melalui kegiatan dan atau pengalamanpengalaman seperti ilmuan (Susilawati, 2013).

Proses belajar mengajar hendaknya mengikutkan siswa secara aktif, guna mengembangkan kemajuan siswa antara lain kemampuan mengobservasi, menginterpretasikan, memprediksi, mengaplikasikan konsep, mengklasifikasi, merencanakan, menggunakan alat, melaksanakan penelitian, serta mengkomunikasikan hasil penemuannya. 
1) Pengamatan (observasi)

Tujuan kegiatan ini untuk melakukan pengamatan yang terarah tentang gejala/fenomena sehingga mampu membedakan yag sesuai dan yang tidak sesuai dalam permasalahan. Yang dimaksud observasi disini adalah penggunaan indera (mata, telinga, penciuman, dan rangsangan) secara optimal dalam rangka memperoleh informasi yang memadai.

2) Menginferensi atau menjelaskan

Menginferensi data ilmiah akan menuntun pada aktivitas memprediksi. Para ilmuan menggunakan pengamatan-pengamatan mutakhir tentang kejadian-kejadian/gejala-gejala untuk membuat ramalan atau untuk membuat generalisasi tentang kejadian-kejadian dimana yang akan datang dipandang dari sudut pandang ilmiah.

3) Menginterpretasi hasil pengamatan

Tujuan kegiatan ini untuk menginterpretasi hasil pengamatan atau pengukuran suatu objek yang telah dilakukan berdasarkan pada pola hubungan antara hasil pengamatan yang satu dengan yang lainnya.

4) Memprediksi

Hasil interpretasi dari suatu pengamatan kemudian digunakan untuk memprediksi kejadian yang belum diamati/ akan datang. Ada perbedaan antara prediksi dan terkesan. Prediksi didasarkan atas hubungan logis dari pengamatan yang telah diketahui, terkesan kurang didasarkan pada hasil pengamatan.

5) Aplikasi konsep

Yang dimaksud dengan aplikasi konsep adalah mengunakan konsep yang telah dipelajari dalam situasi baru atau dalam penyelesaian suatu masalah.

6) Mengklasifikasikan

Ada beberapa cara untuk mengklasifikasikan benda-benda. Ilmuan menggunakan ada atau tidak ada dari sifat-sifat yang dimiliki benda-benda yang bersangkutan (persamaan dan perbedaan), atau hubungan timbal balik untuk menentukan dimana benda tersebut menempati kelompoknya.

7) Perencanaan penelitian

Penelitian bertitik tolak dari seperangkat masalah untuk menguji hipotesis tertentu yang memerlukan perencanaan penelitian lanjutan dalam bentuk percobaan lain.

8) Pelaksanaan penelitian

Berdasarkan rancangan percobaan dilaksanakan penelitian untuk menguji hipotesis.

9) Menggunakan alat/bahan/sumber

Keterampilan menggunakan alat dalam mengukur objek merupakan bagian penting di dalam kehidupan kita sejak dahulu, dan karena adanya pengukuran, ilmuwan dapat membandingkan benda-benda dan kejadian-kejadian secara kuantitatif.

10) Mengkomunikasikan

Kegiatan ini bertujuan untuk mengkomunikasikan proses dan hasil penelitian kepada berbagai pihak yang berkepentingan, baik dalam bentuk kata-kata, grafik, bagan, maupun tabel, secara lisan dan tertulis(Tahwil, M., dan Liliasari, 2014).

\section{Konsep Koloid}

Ketika mempelajari sifat difusi beberapa larutan yang berdifusi melalui membran kertas perkamen, Thomas Graham menemukan bahwa larutan seperti natrium klorida mudah berdifusi, sedangkan zat-zat seperti kanji, gelatin dan putih telur sangat lambat atau sama sekali tidak berdifusi. Oleh karena zat yang mudah berdifusi, biasanya membentuk kristal dalam keadan padat, Graham menyebutnya kristaloid. Sedangkan zat-zat yang sukar berdifusi disebutnya, koloid (bahasa yunani: kola $=$ perekat atau lem $)($ Achmad, H., 1996). 
Tabel 1. Perbandingan Sifat Larutan, Koloid dan Suspensi

\begin{tabular}{|c|c|c|}
\hline $\begin{array}{l}\text { Larutan (Dispersi } \\
\text { Molekuler) }\end{array}$ & Koloid (Dispersi Koloid) & $\begin{array}{c}\text { Suspensi (Dispersi } \\
\text { Kasar) }\end{array}$ \\
\hline 1. Satu fase & 1. Dua fase & 1. Dua fase \\
\hline 2. Homogen & Antara homogen & 2. Heterogen \\
\hline 3. $<1 \mathrm{~nm}$ & heterogen & 3. $>100 \mathrm{~nm}$ \\
\hline 4. Tidakdapat disaring & $1 \mathrm{~nm}<\mathrm{d}>100 \mathrm{~nm}$ & 4. Dapat disaring \\
\hline 5. Tidak terpisah & $\begin{array}{l}\text { 4. Tidak dapat disaring dengan } \\
\text { penyaring biasa } \\
\text { 5. Tidak terpisah }\end{array}$ & $\begin{array}{l}\text { 5. Terpisah (Padatan } \\
\text { mengendap) }\end{array}$ \\
\hline
\end{tabular}

Berdasarkan fasa terdispersi dan fasa pendispersinya, koloid disebut juga dispersi koloid yang dapat dibagi atas delapan jenis(Petrucci, R.H., 2008).

Tabel 2. Jenis Sistem Koloid

\begin{tabular}{cccc}
\hline Fase Terdispesi & $\begin{array}{c}\text { Fase } \\
\text { Pendispersi }\end{array}$ & Nama & Contoh \\
\hline Padat & Cair & Sol & Sol lempung, silica koloid, emas koloid \\
\hline Cair & Cair & Emulsi & Minyak dalam air, susu, mayones \\
\hline Gas & Cair & Busa & $\begin{array}{c}\text { Sabun dan busa detergen, krim kue tar, } \\
\text { kue busa }\end{array}$ \\
\hline Padat & Gas & Aerosol Padat & Asap, udara berdebu \\
\hline Cair & Gas & Aerosol & $\begin{array}{c}\text { Kabut, halimun (seperti pada produk } \\
\text { aerosol) }\end{array}$ \\
\hline Padat & Padat & Sol Padat & $\begin{array}{c}\text { Kaca mirah, beberapa batu mulia alami } \\
\text { dan sintetik, garam tambang biru, intan } \\
\text { hitam }\end{array}$ \\
\hline Cair & Padat & Emulsi Padat & Opal, mutiara \\
\hline Gas & Padat & Busa Padat & Batu apung,lava, abu vulkanik \\
\hline
\end{tabular}

Ditinjau dari interaksi fasa terdispersi dengan fasa pendispersi (medium), koloid dapat pula dibagi atas koloid liofil dan liofob. Koloid liofil, yaitu koloid yang suka berikatan dengan mediumnya sehingga sulit dipisahkan atau sangat stabil. Jika mediumnya air disebut koloid bidrofil, yaitu suka air, contohnya agar-agar dan tepung kanji (amilum) dalam air. Koloid liofob, yaitu koloid yang tidak menyukai mediumnya sehingga cenderung memisah, dan akibatnya tidak stabil. Bila mediumnya air, disebut koloid hidrofob (tidak suka air), contohnya sol emas dan koloid $\mathrm{Fe}(\mathrm{OH})_{3}$ dalam air. Koloid dapat berubah menjadi tidak koloid atau sebaliknya. Berdasarkan perubahan itu ada koloid reversibel dan irrevesibel. Koloid reversibel, yaitu suatu koloid yang dapat berubah jadi tak koloid, dan kemudian menjadi koloid kembali. Contohnya air susu (koloid) bila dibiarkan akan mengendap (tidak koloid) dan airnya terpisah, tetapi bila dikocok akan bercampur seperti semula (koloid). Koloid irreversibel, yaitu koloid yang setelah berubah menjadi bukan koloid tidak dapat menjadi koloid lagi, contohnya sol emas (Syukri, S., 1999).

\section{Sifat-sifat Koloid}

\section{Efek Tyndall}

Jika cahaya matahari menembus melalui celah-celah rumah kita, tampak sinar matahari dihamburkan oleh partikel-partikel debu. Partikel debu terlalu kecil untuk dilihat, akan tampak sebagai titik-titik terang dalam suatu berkas cahaya. Oleh karena partikel debu berukuran koloid, partikelnya sendiri tidak dapat dilihat oleh mata, yang tampak adalah cahaya yang dihamburkan oleh debu. Hamburkan cahaya ini dinamakan efek Tyndall. 
Efek Tyndall dapat digunakan untuk membedakan koloid dari larutan sejati, sebab atom, molekul, atau ion yang membentuk larutan tidak dapat menghamburkan cahaya akibat ukurannya terlalu kecil. Penghamburan cahaya oleh suatu campuran menunjukan bahwa campuran tersebut adalah suatu koloid, dimana ukuran partikel-partikelnya lebih besar dari ukuran partikel dalam larutan, sehingga dapat menghamburkan cahaya(Sunarya, Y., 2011).

\section{Gerak Brown}

Jika suatu mikroskop optis difokuskan pada suatu disperse koloid pada arah yang tegak lurus pada berkas cahaya dan dengan latarbelakang gelap, akan nampak partikel-partikel koloid, bukan sebagai partikel dengan batas yang jelas, melainkan sebagai bintik yang berkilauan. Dengan mengikuti bintik-bintik cahaya yang dipantulkan ini, orang dapat melihat bahwa partikel koloid yang terdispersi ini bergerak terus-menerus secara acak menurut jalan yang berliku-liku.

Gerakan acak partikel koloid dalam suatu medium pendespersi ini disebut gerak Brown, menurut nama seorang ahli botani inggris, Robert Brown yang pertama kali melihat gejala ini tahun 1827.Brown tidak dapat menjelaskan mengapa partikel koloid dapat bergerak lurus dan berliku. Baru pada tahun 1905 gerakan seperti ini dapat dianalisis secara matematis oleh Albert Einstein, yang menyatakan bahwa suatu pertikel mikroskopis yang melayang dalam suatu medium akan menunjukkan suatu gerakan acak seperti gerak Brown akibat banyaknya tumbukan antarmolekul pada sisi-sisi partikel yang tidak sama(Keenan, C.W., 1980).

\section{Adsorpsi}

Atom, molekul, atau ion yang berkerumun membentuk partikel koloid dapat memiliki sifat listrik pada permukaannya. Sifat ini menimbulkan gaya van der waals, bahkan gaya valensi yang dapat menarik dan mengikat atom-atom, molekul atau ion-ion dari zat asing.

Penempelan zat asing pada permukaan suatu partikel koloid disebut adsorpsi. Zat-zat teradsorpsi dapat terikat kuat membentuk lapisan yang tebalnya tidak lebih dari satu atau dua partikel. Banyaknya zat asing yang dapat teradsorpsi bergantung pada luas permukaan partikel koloid. Meskipun adsorpsi merupakan gejala umum dari zat, efisiensi adsorpsi ini bergantung pada besarnya luas permukaan zat pengadsorpsi.Jika permukaan partikel koloid bermuatan positif, maka zat asing yang menempel harus bermuatan negatif. Sebaliknya, jika permukaan partikel koloid bermuatan negatif, maka zat asing yang menempel pada permukaan koloid harus bermuatan positif(Sunarya, Y., 2011).

\section{Koagulasi}

Peristiwa pengendapan atau penggumpalan koloid disebut koagulasi. Koagulasi dapat terjadi dengan cara (1) mencampurkan dua sol yang berbeda muatan, (2) pada elektroforesis muatan sol dinetralkan pada elektroda dan sol mengendap, (3) pemanasan, beberapa sol seperti belerang dan perak halida dapat dikoagulasi dengan pemanasan, (4) penambahan elektrolit,menurut aturan Hardy Schulze, kemampuan mengkoagulasi koloid oleh suatu elektrolit bergantung pada valensi (Achmad, H., 1996).

\section{Kestabilan koloid}

Partikel koloid (seperti sol) bila dibiarkan lambat laun akan menbentuk gumpalan dan mengendap tanpa pengaruh dari luar. Contohnya air susu dan darah bila dibiarkan akan membentuk padatan di dasar bejana. Supaya tidak mengendap, maka koloid harus diberi perlakuan menambahkan ion, dialisis dan menambah emulgator (Syukri, S., 1999). 


\section{Pembuatan Koloid}

Ada dua cara pembuatan koloid yaitu: secara dispersi dan kondensasi. Gumpalan materi atau suspensi kasar dapat diubah menjadi lebih kecil sehingga tersebar dan berukuran koloid. Membuat koloid dengan memecah gumpalan itu disebut dispersi (penyebaran), yaitu dengan cara: (1) Dispersi Mekanik, (2) Dispersi Elektrolitik, (3) Peptisasi. Cara Kondensasi adalah kebalikan dari dispersi, yaitu penggabungan (kondensasi) partikel kecil menjadi lebih besar sampai berukuran koloid. Penggabungan ini terjadi dengan berbagai cara, di antaranya (1) cara reaksi kimia, (2) pertukaran pelarut, (3) pendinginan berlebih (Syukri, S., 1999). Pada kehidupan Sehari-hari koloid digunakan untuk pengendapan cotrell yang digunakan untuk mengurangi polusi udara dari pabrik, pemutihan gula tebu, prinsip dialisis digunakan untuk membantu pasien gagal-ginjal, pembentukan delta di muara sungai, penjernihan air menggunakan alumunium sulfat untuk mengkoagulasi zat pengotor dalam air, sabun sebagai zat pengemulsi untuk menghilangkan zat pengotor yang tidak bercampur dengan air, sebagai bahan makanan dan obat, berbagai kosmetik seperti Body Lotion dan Hand Cream adalah koloid, Alumunium klorida suatu bahan untuk deodorant(Achmad, H., 1996).

\section{METODOLOGI}

Penelitian ini adalah penelitian kuasi eksperimen yang dilakukan terhadap dua kelas, yaitu kelas eksperimen dan kelas kontrol. Penelitian ini dilaksanakan di kelas XI IPA SMA Negeri 10 Pekanbaru pada bulan April-Mei 2018 semester genap tahun ajaran 2017/2018. Teknik pengambilan sampel menggunakan teknik simple random sampling. Berdasarkan teknik sampling tersebut diperoleh kelas XI IPA 3 sebagai kelas eksperimen dan XI IPA 2 sebagai kelas kontrol.

Tabel 3. Nonequivalent Control Group Design.

\begin{tabular}{cccc}
\hline Kelompok & Pre- $\boldsymbol{t e s t}$ & Perlakuan & Post-test \\
\hline Eksperimen & $\mathrm{O}_{1}$ & $\mathrm{X}_{1}$ & $\mathrm{O}_{2}$ \\
\hline Kontrol & $\mathrm{O}_{1}$ & $\mathrm{X}_{2}$ & $\mathrm{O}_{2}$ \\
\hline
\end{tabular}

Keterangan :

$\mathrm{O}_{1: \text { Pretest }}$

$\mathrm{O}_{2:}$ Posttest

$\mathrm{X}_{1}$ : Kelas yang menggunakan model pembelajaran Learning Cycle $7 \mathrm{E}$

$\mathrm{X}_{2}$ : Kelas yang menggunakan model pembelajaran Inkuiri(Emzir, 2015).

Teknik pengumpulan data menggunakan tes essay dan lembar observasi. Tes digunakan untuk mengetahui keterampilan proses sains siswa yang terdiri dari 10 butir soal. Untuk memperoleh tes yang valid, soal terlebih dahulu dianalisis berdasarkan validitas isi dengan guru mata pelajaran kimia dan validitas empiris menggunakan ANATES ver 4.0.5. Soal yang valid adalah soal yang memenuhi taraf signifikan. Dalam teknik analisis lembar observasi yang akan dinilai adalah aspek keterampilan proses sains berupa metode rating scale. Untuk memperoleh lembar observasi yang valid maka lembar observasi di validitas isi dengan dosen pendidikan kimia. Adapun tahapan analisisnya adalah sebagai berikut:

1) Menjumlahkan indikator dari aspek KPS yang diamati

2) Menghitung persentase aspek KPS dalam kelompok dengan rumus (Nurhasanah, 2016).

$$
\text { Persentase }=\frac{\text { skorhasilobservasi }}{\text { skortotal }} \times 100 \%
$$

Teknik analisis data terdiri dari uji prasyarat dan uji hipotesis. Uji Normalitas digunakan untuk mengetahui apakah sampel penelitian ini dari populasi yang normal atau tidak. Sedangkan Uji Homogenitas digunakan untuk mengetahui apakah sampel penelitian ini dari populasi yang 
homogen atau tidak. Dalam penelitian ini, Uji Normalitas yang digunakan adalah metode Kolmogorov-Smirnov dengan bantuan SPSS. Sedangkan untuk menguji Homogenitas digunakan metode Bartlet. Uji Hipotesis yang digunakan adalah uji t.

Prosedur dalam penelitian ini terdiri dari tiga tahap yaitu: tahap persiapan, tahap pelaksanaan, dan tahap akhir.

Tahap Persiapan: (1)Menetapkan kelas penelitian yaitu kelas XI IPA SMAN 10 Pekanbaru tahun ajaran 2017/2018 sebagai subjek penelitian. (2) Menetapkan pokok bahasan yang akan disajikan yaitu mengenai koloid.(3)Mempersiapkan perangkat pembelajaran berupa silabus, program semester, rencana pelaksanaan pembelajaran (RPP), dan bahan-bahan pembelajaran (buku panduan, alat-alat laboratorium). (4) Guru menyiapkan instrumen pengumpulan data (lembar observasi untuk guru dan siswa dan soal pre-test dan post-test). (5) Menentukan kelas eksperimen dan kelas kontrol. (6) Siswa dibagi menjadi 6 kelompok.

Tahap Pelaksanaan: (1) Memberikan soal pre-test kepada kelas eksperimen dan kelas kontrol setelah soal selesai di validasi terlebih dahulu. (2) Pada kelas eksperimen dan kelas kontrol diberikan materi pokok yang sama yaitu mengenai koloid. (3) Pada kelas eksperimen diberikan perlakuan menggunakan model Learning Cycle 7Edan kelas kontrol menggunakan pendekatan saintifik.

Tahap Akhir: Setelah semua pokok bahasan koloid, maka pada kelas eksperimen dan kelas kontrol guru memberikan test akhir (post-test) untuk menentukan pengaruh model pembelajaran model Learning Cycle $7 E$ terhadap keterampilan proses sains siswa. (1) Data akhir (selisih dari pre-test dan post-test) yang diperoleh dari kedua kelas akan dianalisis dengan menggunakan rumus statistik. (2) Pelaporan.

\section{TEMUAN DAN PEMBAHASAN}

Data yang diperoleh dari hasil penelitian ini didapatkan dari hasil penilaian tes dan lembar observasi. Tes yang digunakan dalam peneliitian ini berupa soal essay yang terdiri 10 soal essay. Hasil peningkatan tes keterampilan proses sains dilihat dari rata-rata nilai pretest dan postest di kelas eksperimen dan di kelas kontrol. Hasil tes disajikan padaTabel 4 sebagai berikut.

Tabel 4. Hasil Tes Keterampilan Proses Sains Siswa Berdasarkan Nilai Pretes dan Postest

\begin{tabular}{ccc}
\hline Kelas & Pretest & Posttest \\
\hline Eksperimen & 34,26 & 84,38 \\
\hline Kontrol & 34,97 & 77,55 \\
\hline
\end{tabular}

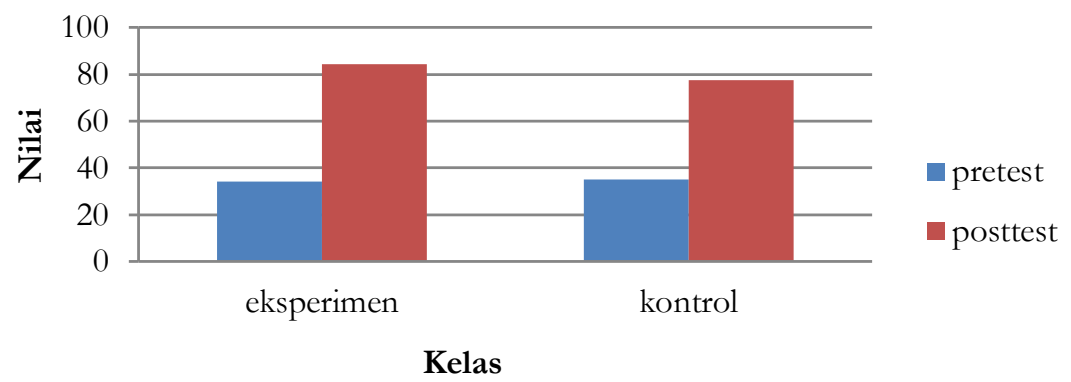

Gambar 1. Hasil Tes Keterampilan Proses Sains

Berdasarkan tabel dan grafik diatas, dapat disimpulkan dari hasil selisih rata-rata nilai pretest dan posttest bahwa keterampilan proses sains sains siswa di kelas eksperimen menunjukkan hasil yang lebih tinggi dibandingkan dengan kelas kontrol. Meningkatnya keterampilan proses sains di 
kelas eksperimen setelah digunakan model pembelajaran Learning Cycle 7E, dikarenakan dalam proses pembelajaran Learning Cycle 7E dapat mengembangkan daya nalar siswa melalui serangkaian kegiatan praktikum selama proses pembelajaran, sehingga terbentuk konsep ilmiah yang dapat meningkatkan keterampilan proses sains siswa. Hal ini sejalan dengan penelitian (Kartikawati, A., \& Utiya Azizah, 2017) bahwa model Learning Cycle dapat mengembangkan pemahaman peserta didik terhadap suatu konsep dengan kegiatan mencoba (band-on activities) sebelum diperkenalkan dengan kata-kata. Learning Cycle juga dapat mengembangkan keterampilan proses peserta didik, memberi kesempatan kepada mereka melakukan percobaan sains secara langsung dan membuat pembelajaran bermakna.

Selain itu, lembar observasi juga digunakan untuk mengukur keterampilan proses sains siswa. Observasi dilakukan terhadap kelas eksperimen dan kelas kontrol yang dibagi menjadi enam kelompok dan dilaksanakan tiga kali pertemuan. Lembar observasi digunakan untuk memantau keterampilan proses sains siswa yang muncul di setiap pertemuan melalui kegiatan praktikum. Skala yang digunakan dalam penelitian ini adalah 1-4 kemudian dikonversikan dalam kategori nilai persentasi.

Tabel 5. Hasil Observasi Keterampilan Proses Sains pada Pertemuan 1, 2, dan 3 Kelas Eksperimen

\begin{tabular}{|c|c|c|c|c|c|}
\hline \multirow{2}{*}{$\begin{array}{c}\text { Aspek } \\
\text { KPS }\end{array}$} & \multicolumn{3}{|c|}{ Pertemuan } & \multirow{2}{*}{ Rata-rata (\%) } & \multirow{2}{*}{ Kesimpulan } \\
\hline & $1(\%)$ & $2(\%)$ & $3(\%)$ & & \\
\hline Observasi & 75,00 & 81,58 & 85,42 & 80,67 & Sangat Baik \\
\hline Klasifikasi & 73,53 & 79,61 & 84,03 & 79,06 & Baik \\
\hline Interpretasi & 72,06 & 76,97 & 80,56 & 76,53 & Baik \\
\hline Melakukan Komunikasi & 72,43 & 77,30 & 80,90 & 76,88 & Baik \\
\hline Mengajukan Pertanyaan & 73,53 & 78,29 & 82,64 & 78,15 & Baik \\
\hline Mengajukan Hipotesis & 70,59 & 73,68 & 78,47 & 74,25 & Baik \\
\hline Menggunakan Alat/Bahan & 75,00 & 80,92 & 84,03 & 79,98 & Baik \\
\hline Menerapkan Konsep & 69,85 & 73,68 & 76,39 & 73.31 & Baik \\
\hline Jumlah & 581,99 & 662,03 & 652,44 & 618,82 & \\
\hline Rata-Rata & 72,75 & 77,75 & 81.56 & 77,35 & Baik \\
\hline
\end{tabular}
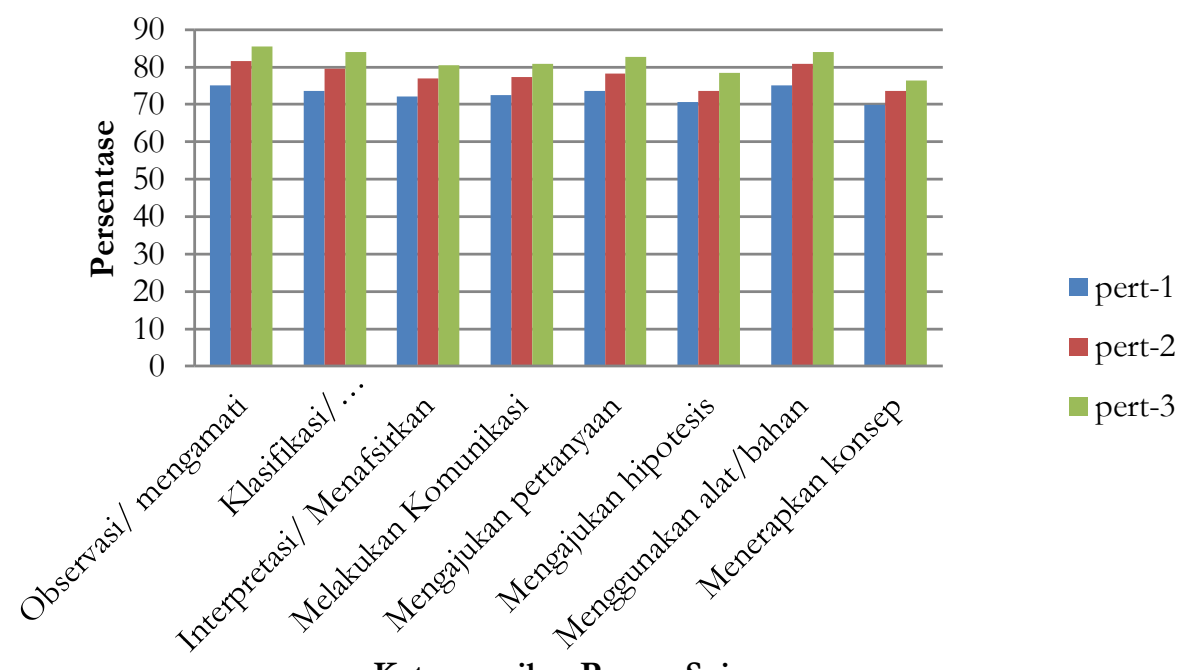

Keterampilan Proses Sains

Gambar 2. Hasil Observasi Keterampilan Proses Sains Kelas Eksperimen

Berdasarkan grafik diatas dapat disimpulkan bahwa hasil lembar observasi secara keseluruhan tiap pertemuan mengalami peningkatan, hal ini menunjukkan bahwa keterampilan 
proses sains siswa semakin baik dengan persentase keterampilan proses sains secara keseluruhan sebesar 77,35\% dengan kategori baik. Dari semua aspek keterampilan proses sains siswa terdapat aspek tertinggi dan terendah. Aspek mengamati (observasi) merupakan aspek yang tertinggi dengan nilai persentase rata-rata sebesar $80,67 \%$. Sedangkan aspek keterampilan proses sains terendah adalah aspek menerapkan konsep dengan nilai persentase rata-rata sebesar $73,31 \%$.

Sebelum melakukan analisis uji hipotesis, terlebih dahulu dilakukan uji prasyarat analisis. Uji yang digunakan adalah: 1) Uji Normalitas; dan 2) Uji Homogenitas. Uji Normalitas dalam penelitian ini menggunakan metode Kolmogorov-Smimov dengan bantuan SPSS 16.0 dan hasilnya dapat dilihat dalam Tabel 6. Uji Homogenitas yang digunakan adalah uji Bartlet dengan taraf signifikansi 5\%.Uji-t dapat dilakukan apabila data memenuhi syarat yaitu normal dan homogen. Data dikatakan normal jika $\mathrm{X}_{\text {hitung }}>\mathrm{X}_{\text {tabel. }}$ Sedangkan data dikatakan homogen jika $\mathrm{X}_{\text {hitung }}>\mathrm{X}_{\text {tabel. }}$

Tabel 6. Hasil Analisis Data Uji Normalitas

\begin{tabular}{ccccc}
\hline \multirow{2}{*}{ Data } & Kelas & $\begin{array}{c}\text { Kolmogorov- } \\
\text { Smirnov Z }\end{array}$ & Sig & Ket \\
\hline \multirow{2}{*}{ Pretest } & Eksperimen & 0,900 & 0,393 & Normal \\
\cline { 2 - 5 } & Kontrol & 0,887 & 0,412 & Normal \\
\hline \multirow{2}{*}{ Posttest } & Eksperimen & 1,089 & 0,187 & Normal \\
\cline { 2 - 5 } & Kontrol & 1,151 & 0,141 & Normal \\
\hline
\end{tabular}

Berdasarkan uji normalitas di atas, diketahui kedua data berdistribusi normal. Hal ini menunjukkan bahwa skor pretest posttest siswa kelas eksperimen dan kontrol berdistribusi normal, sehingga data tersebut layak digunakan untuk menguji analisis lebih lanjut dengan menggunakan uji t.

Tabel 7. Hasil Analisis Uji Homogenitas

\begin{tabular}{ccccc}
\hline Data & Kelas & Levene Statistic & Sig. & Kesimpulan \\
\hline Pretest & $\begin{array}{l}\text { Eksperimen } \\
\text { dan Kontrol }\end{array}$ & 1,908 & 0,172 & Homogen \\
\hline Posttest & $\begin{array}{l}\text { Eksperimen } \\
\text { dan Kontrol }\end{array}$ & 0,319 & 0,574 & Homogen \\
\hline
\end{tabular}

Berdasarkan tabel tersebut diketahui bahwa data pretest posttest kelas eksperimen dengan kelas kontrolmemiliki kesamaan varians, dimana nilai signifikan lebih besar dari 0,05 maka dapat disimpulkan bahwa kedua data memiliki varians yang homogen.

Setelah dilakukan uji normalitas dan uji homogenitas, data hasil penelitian terdistribusi normal dan homogen. Bila pola penelitian dilakukan terhadap 2 kelompok, yang satu merupakan kelompok eksperimen (Learning Cycle 7E) dan kelompok kontrol (Pendekatan Saintifik). Untuk mengetahu t tabel $\mathrm{dk}=\mathrm{Nx}+\mathrm{Ny}-2$. Maka test " $\mathrm{t}$ " yang digunakan dengan Sampel Related. Rangkuman analisis uji hipotesis dapat dilihat pada Tabel 8 di bawah ini.

Tabel 8. Hasil Analisis Data Hipotesis

\begin{tabular}{|c|c|c|c|c|c|c|}
\hline Kelas & $\mathbf{N}$ & $\sum \mathbf{X}$ & $\overline{\boldsymbol{X}}$ & $t_{\text {hitung }}$ & $t_{\text {tabel }}$ & Kesimpulan \\
\hline Eksperimen & 34 & 50,12 & 5013,53 & 2,80 & 2,00 & $\mathrm{H}_{0}$ ditolak \\
\hline Kontrol & 33 & 42,58 & 2812,06 & & & \\
\hline
\end{tabular}

Dari tabel diatas dapat dilihat nilai $t_{\text {hitung }}=2,80$ dan $t_{\text {tabel }}=2,00$ sehingga $t_{\text {hitung }}>t_{\text {tabelpada }}$ taraf signifikan 5\% dengan demikian $\mathrm{H}_{0}$ ditolak, maka hipotesis "Ada pengaruh penerapan model 
pembelajaran Learning Cycle 7Eterhadap keterampilan proses sains siswa pada materi koloid kelas XI SMA Negeri 10 Pekanbaru” diterima.

Berdasarkan data hasil uji " $\mathrm{t}$ ", untuk mengetahui apakah ada pengaruh penerapan model Learning Cycle $7 E$ terhadap keterampilan proses sains siswa pada materi koloid maka dapat juga dilihat derajat pengaruh hasil belajar dengan menghitung koefisien $\left(\mathrm{r}^{2}\right)$ sedangkan untuk melihat koefisien pengaruh $(\mathrm{Kp})$ dengan menggunakan rumus $\mathrm{Kp}=\mathrm{r}^{2} \times 100 \%$. Sehingga diperoleh koefisien pengaruh $(\mathrm{Kp})$ sebesar 10,8\%. Rangkuman hasil pengujian tersebut dapat dilihat pada Tabel 9 di bawah ini.

Tabel 9. Uji $\mathbf{r}^{2}$ dan Kp

\begin{tabular}{cc}
\hline $\mathbf{r}^{2}$ & $\mathbf{K p}$ \\
\hline 0,108 & $10,8 \%$ \\
\hline
\end{tabular}

Berdasarkan tabel 5 dan gambar 2, akan dijelaskan setiap indikator keterampilan proses sains yang di teliti berdasarkan analisis data yang diperoleh. Berikut penjelasan dari keseluruhan indikator.

\section{Observasi/mengamati}

Keterampilan proses sains aspek mengamati (observasi) merupakan aspek yang tertinggi dengan nilai persentase rata-rata sebesar $80,67 \%$ dengan kategori baik. Hal ini dikarenakan pada aspek ini siswa diajak untuk berinteraksi langsung pada objek atau peristiwa sesungguhnya yang terjadi pada saat proses pembelajaran berlangsung, sehingga siswa merasa senang ketika melakukan kegiatan pengamatan. Selain itu, siswa juga sudah terbiasa melakukan pengamatan dalam kehidupan sehari-hari sehingga bukan merupakan hal yang asing lagi bagi siswa untuk mengamati. Aspek mengamati dilakukan pada tahap explore dalam model Learning Cycle7E, dimana keterlaksanaan model Learning Cycle 7E pada aspek mengamati pertemuan I, II, dan III berturutturut sebesar 75,00\%, 81,58\%,85,42\% dan diperoleh rata-rata sebesar 80,67\%. Berikut grafik keterlaksanaan model Learning Cycle $7 E$ pada aspek mengamati pertemuan I, II, dan III.

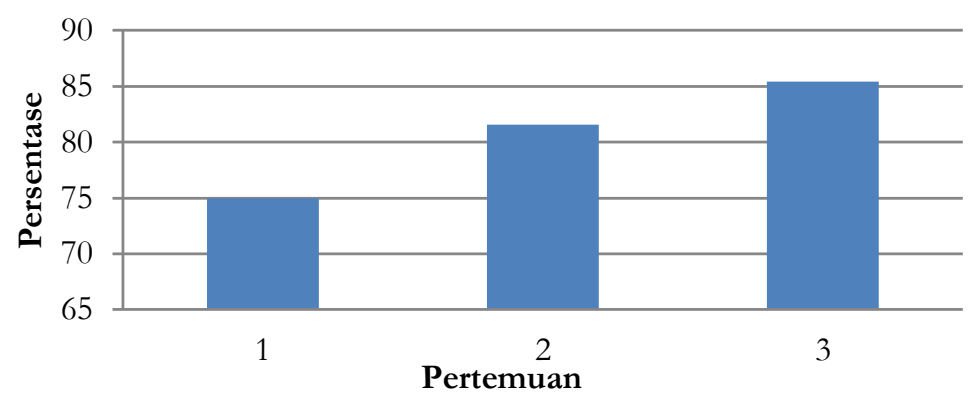

\section{Gambar 3. Aspek Mengamati Pertemuan I, II, dan III}

Dari grafik di atas dapat disimpulkan bahwa aspek mengamati mengalami peningkatan pada setiap pertemuan. Hal ini dikarenakan pada tahap explore dengan menggunakan model Learning Cycle $7 E$ siswa melakukan praktikum pada ketiga pertemuan sehingga dapat melatih keterampilan proses sains siswa selama proses pembelajaran. Hal ini sejalan dengan penilitian (Rani, R. A., Nurislami \& Azhar, 2016) mengatakan bahwa Learning Cycle 7E dapat menunjang peningkatan aspek keterampilan proses mengobservasi. Pada tahap explore siswa dapat mengembangkan indikator mengamati, siswa melaksanakan tahapan eksplorasi dimana siswa memperoleh hasil eksperimen yang akan diterjemahkan dalam bentuk grafik kemudian menentukan hubungan timbal balik dari variabel-variabel yang diuji. 


\section{Klasifikasi/ mengelompokkan}

Keterampilan proses sains aspek mengklasifikasikan dengan nilai persentase rata-rata sebesar 79,06\% dengan kategori baik. Hal ini dikarenakan pada aspek ini siswa sudah di tuntut dengan penggunaan LKPD dimana di dalam LKPD sudah diberikan tabel hasil pengamatan sehingga siswa hanya perlu mengelompokkan dan mencatat setiap hasil pengamatan dengan sistematis. Aspek mengelompokkan ini dilakukan pada tahap explore dalam model Learning Cycle 7E, dimana keterlaksanaan model Learning Cycle $7 E$ pada aspek mengelompokkan pertemuan I, II, dan III berturut-turut sebesar 73,53\%, 79,61\%, 84,03\% dan diperoleh rata-rata sebesar 79,06\%. Berikut grafik keterlaksanaan model Learning Cycle $7 \mathrm{E}$ pada aspek mengelompokkan pertemuan I, II, dan III.

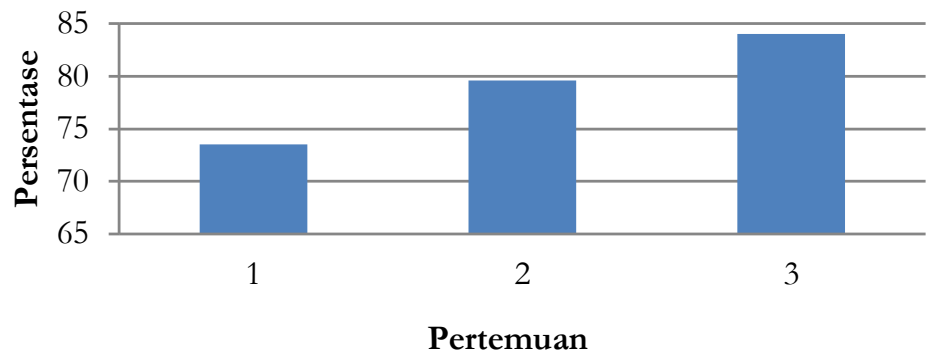

Gambar 4. Aspek Mengelompokkan Pertemuan I, II, dan III

Dari grafik diatas dapat disimpulkan bahwa aspek mengelompokkan juga mengalami peningkatan pada setiap pertemuan. Meningkatnya aspek ini dikarenakan pada setiap pertemuan siswa dilatih mengelompokkan data hasil pengamatan dengan bantuan LKPD pada setiap pertemuan. Menurut (Infantri Putra, A. H., Sri Widoretno, \& Baskoro Adi, 2015)peningkatan aspek keterampilan klasifikasi/ mengelompokkan didukung dengan tingginya peningkatan yang terjadi pada aspek keterampilan observasi. Aspek keterampilan observasi merupakan keterampilan dasar yang harus dimiliki untuk melakukan klasifikasi. Keterampilan observasi merupakan dasar untuk memiliki keterampilan proses sains yang lain.

\section{Interpretasi/ menafsirkan}

Keterampilan proses sains aspek menafsirkan dengan nilai persentase rata-rata sebesar $76,53 \%$ dengan kategori baik. Hal ini dikarenakan pada aspek ini siswa diminta untuk menuliskan kesimpulan hasil pengamatan dalam bentuk tulisan yang ada di dalam LKPD. Dalam aspek menafsirkan, kelengkapan data merupakan syarat wajib agar data dapat dihubungkan antara satu dengan yang lainnya, sehingga siswa mampu untuk menuliskan kesimpulan percobaan berdasarkan dari hasil pengamatan yang di lakukan. Aspek menafsirkan ini dilakukan pada tahap explain dalam model Learning Cycle 7E, dimana keterlaksanaan model Learning Cycle 7E pada aspek menafsirkan pertemuan I, II, dan III berturut-turut sebesar 72,06\%, 76,97\%, 80,56\% dan diperoleh rata-rata sebesar 76,53\%. Berikut grafik keterlaksanaan model Learning Cycle $7 E$ pada aspek menafsirkan pertemuan I, II, dan III.

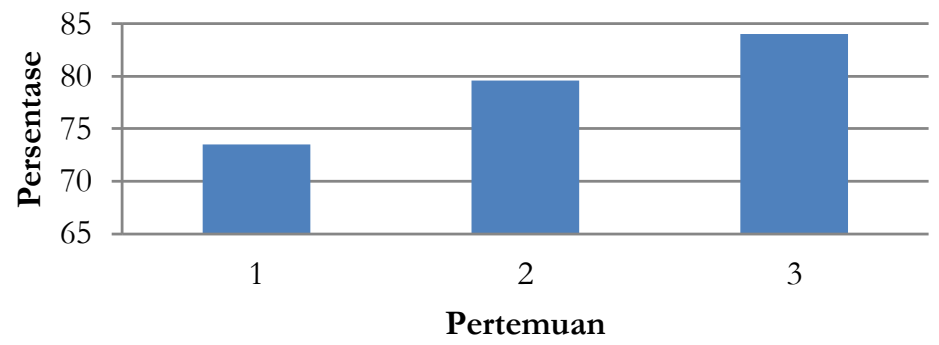

Gambar 5. Aspek Menafsirkan Pertemuan I, II, dan III 
Dari grafik di atas dapat disimpulkan bahwa aspek menafsirkan juga mengalami peningkatan pada setiap pertemuan. Hal ini dikarenakan pada tahap explain dengan menggunakan model Learning Cycle 7E siswa menjelaskan kesimpulan hasil pengamatan yang di tulis di dalam LKPD.

\section{Melakukan komunikasi}

Keterampilan proses sains aspek melakukan komunikasi dengan nilai persentase rata-rata sebesar 76,88\% dengan kategori sangat baik. Hal ini dikarenakan berkomunikasi sudah sering dilakukan dalam kehidupan sehari-hari sehingga membawa pengaruh yang baik bagi siswa dalam memberi pendapat, jawaban, penjelasan atau kesimpulan suatu percobaan yang dipresentasikan di depan kelas dengan menggunakan kata-kata yang mudah dipahami.

Aspek berkomunikasi ini dilakukan pada tahap explain dan evaluate dalam model Learning Cycle 7E, dimana keterlaksanaan model Learning Cycle 7E pada aspek melakukan komunikasi pertemuan I, II, dan III berturut-turut sebesar 72,43\%, 77,30\%, 80,90\% dan diperoleh rata-rata sebesar 76,88\%. Berikut grafik keterlaksanaan model Learning Cycle $7 E$ pada aspek melakukan komunikasi pertemuan I, II, dan III.

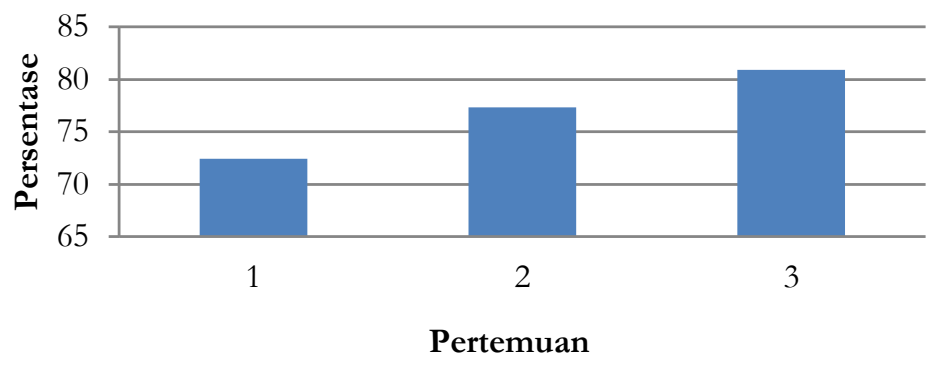

\section{Gambar 6. Aspek Melakukan Komunikasi PertemuanI, II, dan III}

Dari grafik di atas dapat disimpulkan bahwa aspek melakukan komunikasi juga mengalami peningkatan pada setiap pertemuan. Hal ini dikarenakan pada tahap explain dan evaluate dengan menggunakan model Learning Cycle 7E siswa mampu menjelaskan kesimpulan hasil pengamatan yang di tulis di dalam LKPD dan mempresentasikannya di depan kelas serta mampu menjawab pertanyaan dengan benar soal evaluasi di dalam LKPD. Hal ini sejalan dengan penelitian (Infantri Putra, A. H., Sri Widoretno, \& Baskoro Adi, 2015)menyatakan bahwa aspek keterampilan komunikasi lisan mengalami peningkatan pada setiap siklus karena pada fase explanation siswa dituntut untuk mengungkapkan hasil yang diperoleh dari pembelajaran pada fase sebelumnya dengan kalimat siswa sendiri berdasarkan konsep yang sudah didapatkan.

\section{Mengajukan pertanyaan}

Keterampilan proses sains aspek mengajukan pertanyaan dengan nilai persentase rata-rata sebesar 78,15\% dengan kategori baik. Hal ini dikarenakan pada aspek mengajukan pertanyaan siswa sudah terbiasa melakukannya dalam kehidupan sehari-hari sehingga menjadi keterampilan yang cukup baik bagi siswa. Pertanyaan dilakukan oleh guru untuk mengetahui pengetahuan awal siswa dimana pertanyaan tersebut berhubungan dengan kehidupan sehari-hari. Kemudian siswa juga bertanya apabila ada materi yang tidak dipahami.

Aspek mengajukan pertanyaan ini dilakukan pada tahap elecit dalam model Learning Cycle $7 \mathrm{E}$, dimana keterlaksanaan model Learning Cycle $7 \mathrm{E}$ pada aspek mengajukan pertanyaan pertemuan I, II, dan III berturut-turut sebesar 73,53\%, 78,29\%, 82,64\% dan diperoleh rata-rata sebesar 78,15\%. Berikut grafik keterlaksanaan model Learning Cycle $7 \mathrm{E}$ pada aspek mengajukan pertanyaan pertemuan I, II, dan III. 


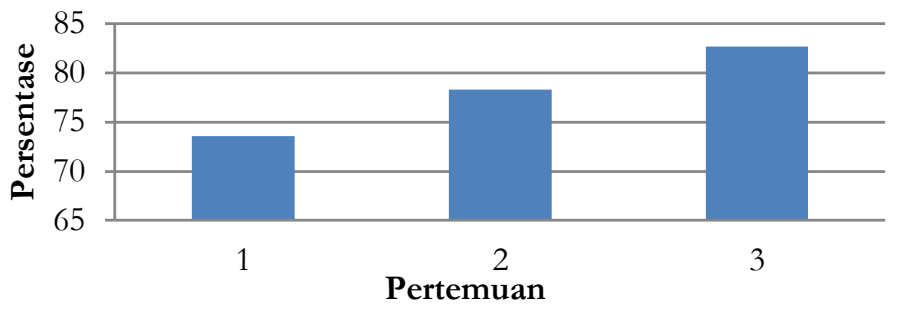

\section{Gambar 7. Aspek Mengajukan Pertanyaan Pertemuan I, II, dan III}

Dari grafik tersebut dapat disimpulkan bahwa aspek mengajukan pertanyaan juga mengalami peningkatan pada setiap pertemuan. Hal ini dikarenakan pada tahap elecit dengan menggunakan model Learning Cycle 7E siswa mampu bertanya ketika guru memberikan pengetahuan awal kepada siswa yang membuat siswa menjadi penasaran dengan materi yang akan di pelajari. Hal ini sejalan dengan penelitian(Zakiyah, R. M., \& Utiya Azizah, 2018)bahwa pada fase elicit pada model pembelajaran Learning Cycle $7 E$ bertujuan untuk memunculkan atau menimbulkan pengetahuan awal peserta didik yang dilakukan melalui pemberian pertanyaan oleh guru terkait materi yang akan dipelajari. Proses menimbulkan pengetahuan sebelumnya merupakan bagian dari pengkonstrusian pengetahuan yang telah dimiliki peserta didik dan juga sebagai komponen yangdiperlukan dalam proses pembelajaran.

\section{Mengajukan hipotesis}

Keterampilan proses sains aspek mengajukan hipotesis dengan nilai persentase rata-rata sebesar 74,25\% dengan kategori baik. Hal ini dikarenakan pada aspek mengajukan hipotesis, siswa mengajukan hipotesis setelah guru mengajak siswa untuk membayangkan, memikirkan dan menduga-duga apa yang akan terjadi. Namun hanya beberapa siswa yang cukup bisa mengajukan hipotesis dengan baik, karena dalam kehidupan sehari-hari siswa kurang dilatihkan dalam hal berhipotesis dalam proses pembelajaran.

Aspek mengajukan hipotesis dilakukan pada tahap engage dalam model Learning Cycle 7E, dimana keterlaksanaan model Learning Cycle $7 \mathrm{E}$ pada aspek mengajukan hipotesis pertemuan I, II, dan III berturut-turut sebesar 70,59\%, 73,68\%, 78,47\% dan diperoleh rata-rata sebesar 74,25\%. Berikut grafik keterlaksanaan model Learning Cycle $7 E$ pada aspek mengajukan hipotesis pertemuan I, II, dan III.

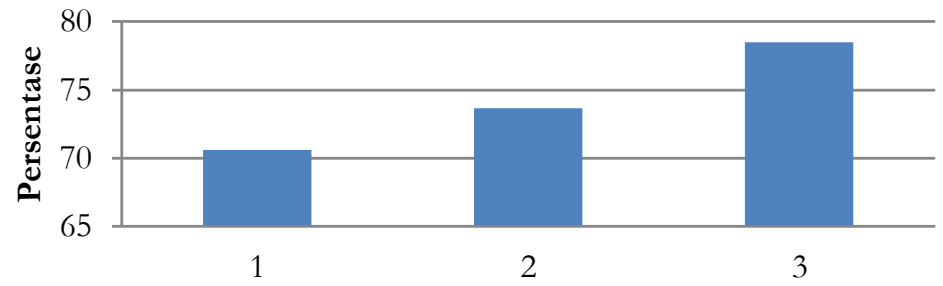

Pertemuan

\section{Gambar 8. Aspek Mengajukan Hipotesis Pertemuan I, II, dan III}

Dari grafik di atas dapat disimpulkan bahwa aspek mengajukan hipotesis juga mengalami peningkatan pada setiap pertemuan. Hal ini dikarenakan pada tahap engage dengan menggunakan model Learning Cycle7E, guru mengajukan pertanyaan yang dapat merangsang ide siswa sehingga siswa diajak berpikir dan berhipotesis terhadap pertanyaan yang guru sampaikan, kemudian hipotesis tersebut dibuktikan dengan praktikum. Hal ini sejalan dengan penelitian (Astupura, D. A., \& Hadma Yuliani, 2016)dimana siswa didorong untuk menguji hipotesis atau membuat 
hipotesis baru, mencoba alternatif pemecahannya dengan teman sekelompok, melakukan dan mencatat pengamatan serta ide-ide atau pendapat yang berkembang dalam diskusi.

\section{Menggunakan alat/bahan}

Keterampilan proses sains aspek menggunakan alat/bahan dengan nilai persentase ratarata sebesar 79,98\% dengan kategori baik. Hal ini dikarenakan pada aspek menggunakan alat/bahan siswa sudah terbiasa melakukannya dalam beberapa kali praktikum yang telah dilakukan oleh guru mata pelajaran kimia disekolah. Hal ini berdasarkan dari hasil wawancara peneliti dengan guru mata pelajaran kimia dimana siswa sudah menerapkan praktikum dibeberapa materi pelajaran seperti asam basa, larutan penyangga dan hidrolisis. Oleh karena itu siswa sudah cukup terbiasa menggunakan alat/bahan praktikum tersebut.

Aspek menggunakan alat/bahan dilakukan pada tahap explore dalam model Learning Cycle 7E, dimana keterlaksanaan model Learning Cycle 7E pada aspek menggunakan alat/bahan pertemuan I, II, dan III berturut-turut sebesar 75,00\%, 80,92\%, 84,03\% dan diperoleh rata-rata sebesar 79,98\%. Berikut grafik keterlaksanaan model Learning Cycle 7E pada aspek menggunakan alat/bahan pertemuan I, II, dan III.

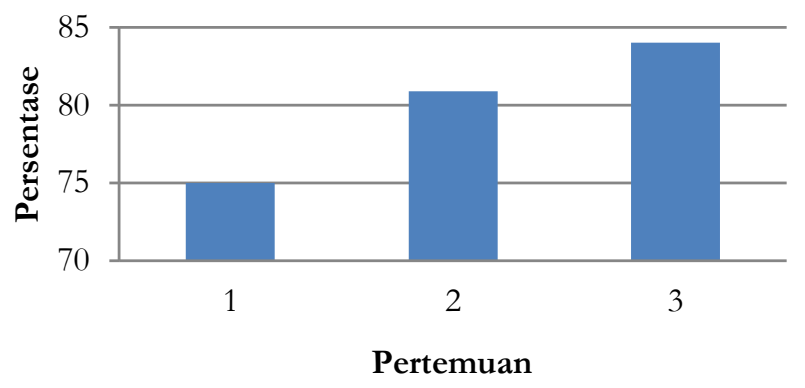

\section{Gambar 9. Aspek Menggunakan Alat/Bahan Pertemuan I, II, dan III}

Dari grafik di atas dapat disimpulkan bahwa aspek menggunakan alat/bahan juga mengalami peningkatan pada setiap pertemuan. Hal ini dikarenakan pada tahap explore dengan menggunakan model Learning Cycle7E siswa dihadapkan langsung pada alat/bahan praktikum, sehingga siswa bisa mencobanya secara sendiri menggunakan alat/bahan. Hal ini sejalan dengan penelitian (Fazri, R. N., Suhartono \& Joharman,2017)bahwa penerapan metode eksperimen pada langkah explore yaitu dengan metode eksperimen merupakan suatu cara guru dalam mengajar siswa melalui kegiatan percobaan yang dilakukan, kemudian siswa mengamati proses dari objek percobaan.

\section{Menerapkan konsep}

Aspek keterampilan proses sains terendah adalah aspek menerapkan konsep sebesar $73,31 \%$, hal ini dikarenakan pada proses pembelajaran siswa diberikan pemahaman baru dimana pemahaman tersebut masih berhubungan dengan praktikum yang dilakukan. Namun siswa kurang bisa dalam menghubungkan pengetahuan yang telah dimilikinya ke dalam pengetahuan baru dikarenakan masih ada beberapa siswa yang belum memahami materi secara keseluruhan yang dibuktikan dengan jawaban siswa dalam fase extend dalam LKPD. Selain itu siswa juga belum terbiasa dan kurang berlatih dalam menerapkan konsep dalam kehidupan sehari-hari.

Aspek menerapkan konsep dilakukan pada tahap elaborate dan extend dalam model Learning Cycle 7E, dimana keterlaksanaan model Learning Cycle 7E pada aspek menggunakan alat/bahan pertemuan I, II, dan III berturut-turut sebesar 69,85\%, 73,68\%, 76,39\% dan diperoleh rata-rata sebesar 73,31\%. Berikut grafik keterlaksanaan model Learning Cycle 7E pada aspek menerapkan konsep pertemuan I, II, dan III. 


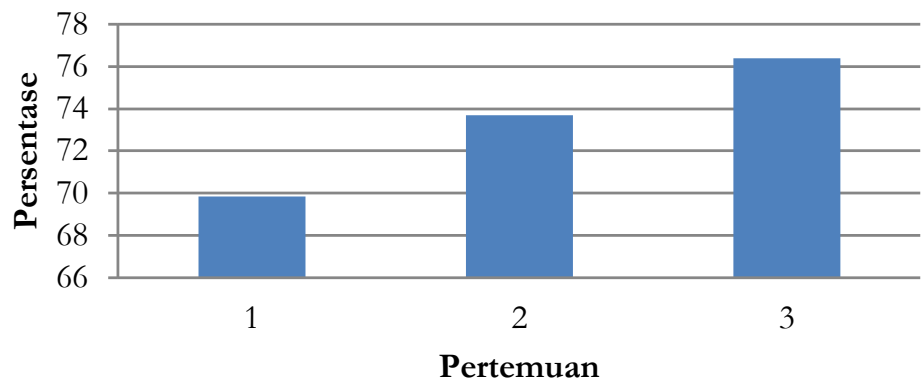

Gambar 10. Aspek Menerapkan Konsep Pertemuan I, II, dan III

Dari grafik di atas dapat disimpulkan bahwa aspek menerapkan konsep juga mengalami peningkatan pada setiap pertemuan, namun peningkatan ini lebih rendah dari aspek keterampilan proses yang lain. Hal ini dikarenakan pada tahap elaborate dan extend dengan menggunakan model Learning Cycle 7E siswa kurang mampu menjawab pertanyaan yang telah disajikan dalam LKPD pada tahap elaborate dan extend yang mana pertanyaan tersebut membuat siswa menerapkan konsep yang telah dipelajarinya kedalam kehidupan sehari-hari. Hal ini sejalan dengan penelitian (Rani, R. A., Nurislami \& Azhar, 2016) dimana pada aspek keterampilan menerapkan konsep siswa diharapkan dapat menggunakan konsep yang telah dipelajarinya dalam situasi baru atau menerapkan konsep itu pada pengalaman-pengalaman baru untuk menjelaskan apa yang sedang terjadi. Berikut kesimpulan data hasil observasi keterampilan proses sains pertemuan 1, 2 dan 3.

Tabel 10. Kesimpulan Data Hasil Observasi Keterampilan Proses Sains

\begin{tabular}{|c|c|c|c|c|c|}
\hline \multirow{2}{*}{ Kelas } & \multicolumn{3}{|c|}{ Rata-rata Pertemuan } & \multirow{2}{*}{$\begin{array}{c}\text { Rata-rata KPS } \\
(\%)\end{array}$} & \multirow{2}{*}{ Keterangan } \\
\hline & $(\%)$ & $(\%)$ & $(\%)$ & & \\
\hline Eksperimen & 2,75 & 7,75 & 1,56 & 77,35 & Baik \\
\hline Kontrol & 7,47 & 1,61 & 3,35 & 70,81 & Baik \\
\hline
\end{tabular}

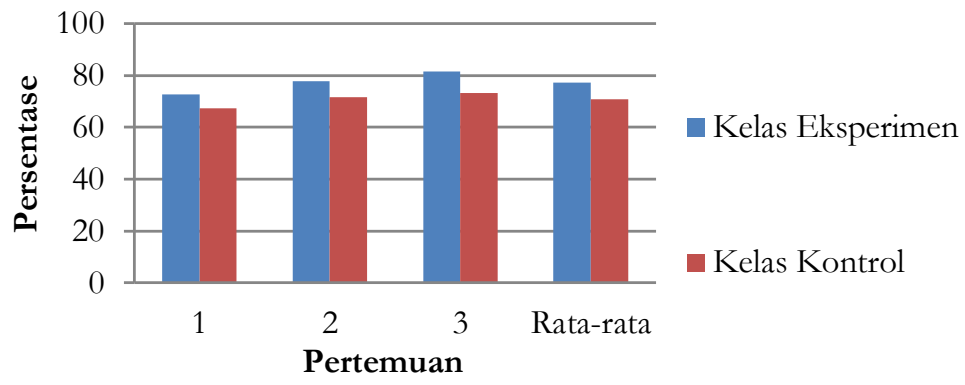

Gambar 11. Kesimpulan Data Hasil Observasi Keterampilan Proses Sains

Berdasarkan hasil lembar observasi di atas, diketahui bahwa keterampilan proses sains kelas eksperimen lebih tinggi daripada kelas kontrol dengan persentase rata-rata keterampilan proses sains di kelas eksperimen sebesar 77,35\% dan di kelas kontrol sebesar 70,81\%. Hal ini dikarenakan pada kelas eksperimen menggunakan model Learning Cycle 7E, dimana model ini dapat membuat siswa melatih keterampilan proses sains yang dimilikinya dengan pelaksanaan belajar seperti praktikum. Menurut (Kartikawati, A., \& Utiya Azizah, 2017)model pembelajaran Learning Cycle $7 E$ merupakan suatu model pembelajaran yang berbasis konstruktivis yang mengakibatkan peserta didik dapat mengembangkan pemahaman terhadap pengetahuan yanng diterima melalui kegiatan mencoba dan diskusi atau memperoleh informasi dari buku sehingga pengetahuan yang diperoleh akan lebih bermakna, selain itu melalui tahapan-tahapan model pembelajaran Learning Cycle $7 E$ ini peserta didik dapat melatihkan keterampilan proses sains. 
Pelaksanaan pembelajaran menggunakan model pembelajaran Learning Cycle $7 \mathrm{E}$ yaitu peserta didik telah dibagi kedalam 6 kelompok yang masing-masing terdiri dari 6-7 orang. Tahaptahap model pembelajaran Learning Cycle $7 E$ terdiri dari 7 fase yaitu elicit, engage, explore, explain,elaborate, evaluate, dan extend.

Fase 1 pada model Learning Cycle $7 E$ yaitu elicit. Tujuan dari fase elicit ini adalah untuk memunculkan atau menimbulkan pengetahuan awal siswa yang dilakukan dengan mengajukan pertanyaan oleh siswa terkait materi yang akan dipelajari, dan mengajukan pertanyaan oleh guru untuk menimbulkan pengetahuan awal siswa. Proses menimbulkan pengetahuan awal sebelumnya merupakan pengetahuan yang telah dimiliki oleh siswa dan juga sebagai komponen yang diperlukan dalam proses pembelajaran. Menurut (Sri Ratna Dewi, N. P., I Made Citra Wibawa \& Ni Luh Pande Latria Devi, 2017)pada tahap elicit, pengetahuan awal siswa akan digali sehingga siswa dapat mengembangkan ide-ide yang telah dimiliki pada tahap selanjutnya.

Fase 2 pada model Learning Cycle 7E yaitu engage. Kegiatan guru dalam merangsang ide dan memotivasi siswa, sedangkan dalam aspek keterampilan proses sains adalah siswa mengajukan hipotesis. Guru memancing siswa untuk mengajukan hipotesis dengan pertanyaan yang diberikan, sedangkan siswa mengajukan hipotesis dari pertanyaan guru tersebut. Dalam fase ini guru dan siswa saling bertukar informasi tentang pengalaman, misalnya pengalaman tentang bagaimana cara melarutkan gula, membuat kopi dan sebagainya yang kemudian dihubungkan dengan materi yang akan dipelajari untuk memotivasi siswa sehingga siswa lebih tertarik untuk belajar. Tujuan dari fase engage ini untuk memfokuskan perhatian, membangkitkan motivasi, dan mengembangkan rasa keingintahuan siswa. Menurut (Sri Ratna Dewi, N. P., I Made Citra Wibawa \& Ni Luh Pande Latria Devi, 2017) pada tahap engage, siswa dimotivasi untuk mengetahui lebih banyak materi yang akan dipelajari dengan cara menghadapkan siswa dengan suatu fenomena yang bertentangan dengan kognitif mereka.

Fase 3 pada model Learning Cycle 7E yaitu explore. Pada fase explore siswa diberikan kesempatan untuk mengamati setiap langkah percobaan, menentukan alat dan bahan dan mengelompokkan hasil dari setiap percobaan yang dilakukan. Pada tahap ini siswa dapat melihat objek yang akan diteliti secara langsung dengan melakukan praktikum, sehingga aspek keterampilan proses sains siswa lebih tinggi pada tahap ini. Fase 4 pada model Learning Cycle $7 \mathrm{E}$ yaitu explain. Pada fase ini siswa menuliskan hasil pengamatan dan menjelaskan kesimpulan dari hasil percobaan yang dilakukan, dimana sebelumnya siswa telah berdiskusi terlebih dahulu dengan teman satu kelompoknya. Kemudian, tugas guru memberikan pengetahuan tentang koloid dan meluruskan jawaban siswa.

Hal ini sejalan dengan penelitian (Kartikawati, A.,\& Utiya Azizah, 2017)menyatakan bahwa model Learning Cycle dapat mengembangkan pemahaman peserta didik terhadap suatu konsep dengan kegiatan mencoba (hand-on activities) sebelum diperkenalkan dengan kata-kata. Learning Cycle juga dapat mengembangkan keterampilan proses peserta didik, memberi kesempatan kepada mereka melakukan percobaan sains secara langsung dan membuat pembelajaran bermakna. Menurut (Fazri, R. N., Suhartono \& Joharman, (2017)metode eksperimen merupakan suatu cara guru dalam mengajar siswa melalui kegiatan percobaan yang dilakukan, kemudian siswa mengamati proses dari objek percobaan, menuliskan hasilnya, mempresentasikan di depan kelas, dan dievaluasi oleh guru.

Fase 5 pada model Learning Cycle 7E yaitu elaborate. Pada fase ini guru memberikan pertanyaan kepada siswa (dalam LKPD), dimana pertanyaan tersebut berhubungan dengan penerapan konsep materi yang sedang di pelajari sehingga siswa harus mampu memecahkan masalah yang diberikan oleh guru. Hal ini sejalan dengan penelitian (Rohaniyah, W.,\&Utiya Azizah, 2017) bahwa kegiatan siswa pada fase explain dapat dilakukan dengan menerapkan konsep sesuai dengan materi yang dipelajari. Fase kelima ini juga dapat dilakukan dengan proses pemecahan masalah oleh siswa. 
Selanjutnya fase 6 pada model Learning Cycle $7 E$ yaitu evaluate. Fase evaluate bertujuan untuk mengetahui pemahaman siswa terhadap konsep yang dipelajari. Tes pada fase evaluate mencakup pertanyaan dari kegiatan praktikum yang telah siswa lakukan. Hal ini sejalan dengan penelitian(Sangadji La Ada,A. F., Rini \& Johni Azmi, 2017) bahwa tahap evaluate (mengevaluasi) pada kegiatan penutup untuk mengevaluasi kemampuan kognitif peserta didik terhadap materi yang diajarkan.

Sedangkan fase 7 pada model Learning Cycle 7Eextend. Pada proses pembelajaran, siswa diberikan fenomena atau pertanyaan pemahaman baru di dalam LKPD dimana pemahaman tersebut masih berhubungan dengan praktikum yang dilakukan. Hal ini sejalan dengan penelitian (Rohaniyah, W.,\& Utiya Azizah, 2017) bahwakegiatan pada fase extend dapat berupa soal-soal penerapan konsep.

Dari pengolahan data analisa uji hipotesis pada tabel 8 , diperoleh nilai thitung $=2,80$ dan nilai $t_{\text {tabel }}=2,00$, hal ini menunjukkan bahwa $t_{\text {hitung }}>t_{\text {tabel }}$ sehingga $\mathrm{H}_{o}$ ditolak dan $\mathrm{H}_{\mathrm{a}}$ diterima. Dengan demikian, dapat disimpulkan bahwa penerapan model pembelajaran Learning Cycle 7E berpengaruh terhadapketerampilan proses sains siswa kelas XI pada materi koloid dengan besar pengaruh $10,8 \%$.

\section{SIMPULAN}

Berdasarkan hasil penelitian, dapat disimpulkan bahwa ada pengaruh penerapan model Learning Cycle 7E terhadap keterampilan proses sains kelas XI SMA Negeri 10 Pekanbaru pada materi koloid. Hal ini dapat dilihat dari nilai $t_{\text {hitung }}>t_{\text {tabel, }}$, dimana $t_{\text {hitung }}=2,80$ sedangkan nilai $t_{\text {tabel }}$ pada taraf signifikan $5 \%=2,00$. Rata-rata nilai postest dari kelas eksperimen adalah 84,38 sedangkan rata-rata nilai postest kelas kontrol adalah 77,55. Pengaruh model Learning Cycle 7E terhadap keterampilan proses sains kelas XI SMA Negeri 10 Pekanbaru pada materi koloid pada kelas eksperimen memiliki pengaruh sebesar 10,8\%. Keterlaksanaan model Learning Cycle 7E terhadap keterampilan proses sains siswa pada materi koloid mendapat kategori baik, dengan persentase rata-rata aspek mengamati sebesar 80,67\%, aspek mengelompokkan sebesar 79,06\%, aspek menafsirkan sebesar 76,53\%, aspek melakukan komunikasi sebesar 76,88\%, aspek mengajukan pertanyaan sebesar $78,15 \%$, aspek mengajukan hipotesis sebesar $74,25 \%$, aspek menggunakan alat/bahan sebesar 79,98\%, dan aspek menerapkan konsep sebesar 73,31\%.

\section{REFERENSI}

Ahmad, H. (1996). Kimia Larutan. Bandung: PT Citra Aditya Bakti.

Astupura, D. A., dan Hadma Yuliani. (2016). Penerapan Model Pembelajaran Learning Cycle terhadap Motivasi dan Keterampilan Proses Sains pada Materi Pokok Cahaya. Jurnal Edusains, 4 (1), 15-27.

Avianti, R., dan Bertha, Y. (2015). Keterampilan Proses Sains Siswa melalui Penerapan Model Pembelajaran Kooperatif Materi Asam Basa Kelas XI SMAN 8 Surabaya. Jurnal Pendidikan Kimia, 4 (2), 224-231.

Departemen Agama RI. (2007). Al-Qur'an dan Terjemahannya. Surabaya: Mega Jaya Abadi.

Diana Rosa, D., dan Utiya Azizah. (2017). Keterampilan Generik Sains Siswa melalui Penerapan Model Pembelajaran Learning Cycle 7E pada Materi Laju Reaksi di SMA Negeri 1 Taman. UNESA Journal Of Chemical Education, 6 (2), 162-167. 
Emzir. (2015). Metodologi Penelitian Pendidikan Kuantitatif dan Kualitatif. Jakarta: Rajawali Pers.

Fazri, R. N., Suhartono dan Joharman. (2017). Penerapan Model Learning Cycle 7E dengan Metode Eksperimen untuk Meningkatkan Pembelajaran IPA Tentang Gaya di Kelas V SD. Jurnal Kalam Cendekia, 5 (2.1), 121-125.

Hilman. (2014). Pengaruh Pembelajaran Inkuiri Terbimbing dengan Mind Map terhadap Keterampilan Proses Sains dan Hasil Belajar IPA. Jurnal Pendidikan Sains, 2 (4), 221-229.

Infantri Putra, A. H., Sri Widoretno, dan Baskoro Adi. (2015). Peningkatan Keterampilan Proses Sains (KPS) Dasar Siswa melalui Penerapan Model Learning Cycle 5E di Kelas VIII G SMP Negeri 22 Surakarta Tahun Pelajaran 2012/2013. Jurnal Pendidikan Biologi, 7 (1), 89-100.

Kartikawati, A., dan Utiya Azizah. (2017). Keterampilan Proses Sains Peserta Didik melalui Penerapan Model Pembelajaran Learning Cycle 7E pada Materi Laju Reaksi Kelas XI di SMA Negeri 1 Krembung. UNESA Journal Of Chemical Education, 6 (2), 229-237.

Keenan. C. W. (1980). Kimia untuk Universitas. Jakarta: Erlangga.

Nurhasanah. (2016). Penggunana Tes Keterampilan Proses Sains (KPS) Siswa dalam Pembelajaran Konsep Kalor dengan Model Inkuiri Terbimbing. Skripsi UIN Sunan Kalijaga.

Permana, N. D. (2018). Penerapan Model Pebelajaran Learning Cycle 7E Berbantuan Website untuk Meningkatkan Keterampilan Berpikir Kritis Siswa pada Materi Kinematika Gerak Lurus. Journal of Natural Science and Integration, 1 (1), 11-41.

Permana, N. D., Ida Hamidah \& Agus Setiawan. (2015). Penggunaan Website dalam Penerapan Model Pembelajaran Learning Cycle 7E untuk Meningkatkan Pemahaman Konsep Siswa pada Materi Kinematika Gerak Lurus. Gravity: Jurnal Ilmiah Penelitian dan Pembelajaran Fisika. 1(1).

Petrucci, Ralph H. (2008). Kimia Dasar Prinsip dan Terapan Modren Edisi Keempat Jilid 2. Jakarta: Erlangga.

Purba, M. N., dan Ila Rosilawati, Tasviri Efkar.( 2016).Efektivitas Discovery Learning pada Materi Koloid dalam Meningkatkan Keterampilan Mengelompokkan dan Mengomunikasikan. Jurnal Pendidikan dan Pembelajaran Kimia, 5 (3), 39-51.

Rani, R. A., Nurislami dan Azhar. (2016). Pembelajaran Fisika dengan Model Learning Cycle 7E pada Materi Listrik Dinamis untuk Meningkatkan Keterampilan Proses Siswa Kelas X SMA Negeri 4 Pekanbaru. Jurnal Pendidikan Fisika.

Rohaniyah, W., dan Utiya Azizah. (2017). Penerapan Model Learning Cycle 7E untuk Meningkatkan Keterampilan Proses Sains pada Materi Laju Reaksi. UNESA Journal Of Chemical Education, 6 (2), 174-178. 
Sangadji La Ada, A. F., Rini dan Johni Azmi. (2017). Penerapan Model Pembelajaran Learning Cycle 7E untuk Meningkatkan Hasil Belajar Peserta Didik pada Pokok Bahasan Koloid di Kelas XI IPA SMAN 6 Pekanbaru. Jurnal Pendidikan Fisika.

Sri Ratna Dewi, N. P., I Made Citra Wibawa, dan Ni Luh Pande Latria Devi. (2017). Kemampuan Berpikir Kritis dan Keterampilan Proses dalam Pembelajaran Siklus Belajar 7E Berbasis Kearifan Lokal. Jurnal Pendidikan Indonesia, 6 (1), 2541-7207.

Sunarya, Yayan. (2012). Kimia Dasar 2. Bandung: CV Yrama Widya.

Susilawati. (2013). Pembelajaran IPA di Madrasah Ibtidaiyah. Pekanbaru: Benteng Media.

Syukri, S. (1999). Kimia Dasar 2. Bandung: ITB.

Tahwil, M., dan Liliasari. (2014). Keterampilan-Keterampilan Sains dan Implementasinya dalam Pembelajaran IPA. Makasar: Badan Penerbit UNM.

Tania, Bella dan Murni. (2017). Penerapan Model Pembelajaran Learning Cycle 5E untuk Meningkatkan Keterampilan Proses Sains Siswa. Jurnal Ilmiah Penelitian dan Pembelajaran Fisika, 3 (1), 66-79.

Trianto. (2011). Model Pembelajaran Terpadu: Konsep, Strategi, dan Implementasinya dalam Kurikulum Tingkat Satuan Pendidikan (KTSP). (Jakarta: Bumi Aksara).

Wahyudi, A., dan Marjono, Harlita. (2015). Pengaruh Problem Based Learning terhadap Keterampilan Proses Sains dan Hasil Belajar Biologi Siswa Kelas X SMA Negeri Jumapolo Tahun Pelajaran 2013/2014. Jurnal Bio-Pedagogi, 4 (1), 5-11.

Yunita. (2012). Model-Model Pembelajaran Kimia. Bandung: CV Insan Mandiri.

Zakiyah, R. M., dan Utiya Azizah. (2018). Penerapan Model Pembelajaran Learning Cycle 7E untuk Melatihkan Keterampilan Proses Sains Peserta Didik pada Materi Reaksi Reduksi dan Oksidasi Kelas X SMA. UNESA Journal Of Chemical Education, 7 (2), 117-122. 